\title{
Effectiveness of social work intervention with a systematic approach to improve general health in opioid addicts in addiction treatment centers
}

This article was published in the following Dove Press journal:

Psychology Research and Behavior Management

17 November 2016

Number of times this article has been viewed

\author{
Ghoncheh Raheb ${ }^{1,2}$ \\ Esmat Khaleghi' \\ Amir Moghanibashi- \\ Mansourieh' \\ Ali Farhoudian ${ }^{2}$ \\ Robab Teymouri ${ }^{3}$ \\ 'Department of Social Work, \\ University of Social Welfare and \\ Rehabilitation Sciences, Tehran, Iran; \\ ${ }^{2}$ Substance Abuse and Dependence \\ Research Center, University of \\ Social Welfare and Rehabilitation \\ Sciences, Tehran, Iran; ${ }^{3}$ Pediatric \\ Neurorehabilitation Research Center, \\ University of Social Welfare and \\ Rehabilitation Sciences, Tehran, Iran
}

Correspondence: Robab Teymouri Pediatric Neurorehabilitation Research Center, University of Social Welfare and Rehabilitation Sciences, Koodakyar Avenue, Daneshjoo Boulevard, Evin, Tehran 19857।3834, Iran

Tel +982122180099

$\mathrm{Fax}+982122180095$

Email robab.teymouri@yahoo.com
Purpose: This study takes a systematic approach to investigate the effect of social work intervention aimed at increasing general health among opioid addicts in addiction treatment centers. Patients and methods: This is an experimental plan (pretest to posttest with a control group); the study sample included 60 patients with drug dependencies undergoing treatment in addiction treatment centers. These patients were randomly assigned as case (30) and control (30) groups. The case group was subjected to intervention over ten sessions, whereas the control group received no intervention. Both groups then passed through a posttest, while a follow-up was conducted after 4 months. Data were obtained via a General Health Questionnaire.

Results: A covariance analysis test and independent and dependent $t$-test results indicated that a social work intervention adopting systematic approach was effective in increasing the general health of drug-addicted patients under treatment.

Conclusion: Thus, the nature of the presence of social workers in addiction treatment centers has been effective and can have a significant influence by reducing anxiety and insomnia and somatic symptoms, improving patients' self-understanding and self-recognition, and enhancing social functioning.

Keywords: social work, intervention, systematic approach, general health, opioid addicts

\section{Introduction}

Currently, addiction has changed into a plight for the general health around the world. ${ }^{1}$ Similarly, in Iran, despite lack of existence of accurate statistics about the number of addicts, ${ }^{2}$ over the last few years, the extent of abusing stimulants including opioids has been increasing. ${ }^{3}$ Today, many studies have confirmed the symbiosis of drug dependence disorders and mood disorders. ${ }^{4,5}$ The results of studies conducted in Iran also show that mental health among drug abusers is significantly lower than that in healthy individuals. ${ }^{6-10}$ Furthermore, investigations reveal that addicts have paranoid thinking, signs of depression, anxiety, obsessive thoughts, low self-confidence, and phobia. ${ }^{11}$ In general, research has shown that general health is low among addicts. ${ }^{12}$

General health ensures provision and preservation of psychological, individual, and social health, such that the person is able to do his/her activities well and establish proper relationship with his/her family members and environment and has no improper behavior according to the culture and society. Therefore, disorders in the general health result in physical, psychological, and social problems; thus, addiction is considered as a disorder in general health. ${ }^{13}$ 
Historically, social workers have been providing essential services for people with a background of drug abuse disorders. ${ }^{14}$ According to the definition of the National Association of Social Workers, the principal mission of social workers is to enhance people's health, along with empowerment of vulnerable individuals to enable them to meet their primary needs. ${ }^{15}$ Insistence on employing evidence-based social psychotherapies by social workers has been increasing in the last two decades for the treatment of people suffering from drug abuse disorders. ${ }^{16}$ Social workers use basic professional principles, skills, and values in the delivery of professional social work services, thus helping the addict to stop his/ her drug abuse, prevent the incidence of addiction-related problems, solve his/her life problems, and improve his/her performance in psychosocial aspects. ${ }^{17,18}$

Treatment in social work is successful if self-esteem is enhanced in clients, strengthening the skills that enable them to have control over their environment, increasing interpersonal skills while modifying work habits, and helping individuals to acquire a controllable and satisfactory environment. ${ }^{17,18}$ Thus, a systematic approach toward the problem requires the application of multidimensional treatment methods, which emphasizes the biological, psychological, social, and environmental aspects of long-term recovery. ${ }^{17,18}$

Social workers attempt to eliminate drug abuse-related behavior in addition to detoxification as the first intervention action in systematic approach. They thus try to improve the social, professional, and psychological performance of the addict. In the second step, social workers apply rehabilitation in areas such as professional performance, mental health, and community participation in order to prevent recurrence of addiction. They then help the patient to identify the resources they possess, including personal, environmental, and family resources, thus increasing them. When considering humanities research into the status of social work and its possible role in issues such as recurring drug abuse, the research question to be currently raised is as follows: does social work intervention with a systematic approach influence on increasing the general health of opioid addicts?

\section{Patients and methods}

The ethical approval for this study was obtained from the Ethics Committee of University of Social Welfare and Rehabilitation Sciences and written informed consent was obtained from all patients. This was a quasiexperimental study. In this study, an experimental plan with a control group was used, involving a pretest and a posttest. The statistical population included men referred to drug addiction treatment centers in Guilan Province, Iran, from December 2013 to
June 2014. A total of 280 patients were undergoing treatment, of whom, based on the inclusion criteria (including having a negative test for opioid addiction at the same time, aged 20-60 years, addiction duration between 2 and 8 years, having the ability of reading and writing, getting married, and kind of abused drugs including opium and methamphetamine), 70 patients who had compliance with these requirements were selected by availability sampling; four people were not willing to participate in the study and six patients withdrew from the study during the intervention.

Thus, 60 patients were selected as the statistical sample and randomly assigned into case and control groups. Social work intervention with systematic approach was conducted on the case group (30 patients), whereas there was no such intervention on the control group (30 patients).

The data collection tools included a demographic questionnaire and the 28-item General Health Questionnaire (GHQ). This questionnaire was originally formulated using a factor analysis with a long form. It includes four subscales (somatic symptoms, anxiety and insomnia, social dysfunction, and severe depression), each of which includes seven subitems. The validity of this questionnaire was reported as $80 \%{ }^{20}$ The reliability of the questionnaire was obtained as 0.88 using the Statistical Package of the Social Sciences software and Cronbach's $\alpha$. The process of social work with patients is shown in Table $1 .^{17}$

Treatment sessions were performed in individual treatment and group therapy. Individual treatments were counseling, home visits, and intervention in family and at work in order to resolve problems. Group sessions for group therapy were carried out in addiction treatment centers.

\section{Data analysis}

Descriptive statistics and inferential statistics were performed. In the descriptive section, the frequency tables and the percentage of demographic variables were presented in both groups, and in the inferential section, independent and dependent $t$-tests and covariance analysis were used. The significance level for all tests was 0.05 .

\section{Results}

The demographic characteristics of both groups are presented in Table 2.

\section{Kolmogorov-Smirnov test results}

As Kolmogorov-Smirnov test shows, all the quantitative variables had a normal distribution, and $P>0.05$ indicates that the two groups were somehow equivalent in terms of the distribution of variables (Table 3). 
Table I Process of social work intervention pattern based on a systematic approach

\begin{tabular}{|c|c|c|c|}
\hline Session number & Intervention (activity) & Goal & Intervention type \\
\hline Session I & $\begin{array}{l}\text { Establishing professional communication } \\
\text { and motivational interview }\end{array}$ & $\begin{array}{l}\text { Establishment of effective communication between } \\
\text { social worker and patient } \\
\text { Motivating patient in order to change him/her and } \\
\text { preparations for interventional program }\end{array}$ & Individual \\
\hline Session 2 & Recognizing the patient & $\begin{array}{l}\text { Evaluation of person (genogram, eco-mapping, } \\
\text { mental health, social support resources) }\end{array}$ & Individual \\
\hline Session 3 & & Evaluation of family & Family \\
\hline Session 4 & & Evaluation of social environment and functions & Individual \\
\hline Session 5 & Recognizing the problem and etiology & $\begin{array}{l}\text { Understanding the problem (etiology, dynamics, and } \\
\text { treatment) }\end{array}$ & Individual \\
\hline Session 6 & Solving the problem and its dynamics & Problem solving & Individual \\
\hline Session 7 & $\begin{array}{l}\text { Therapeutic strategies for familial } \\
\text { treatment of an addict }\end{array}$ & $\begin{array}{l}\text { Modification of family relations and interpersonal } \\
\text { relations, strengthening supportive sources }\end{array}$ & Family \\
\hline Session 8 & Strategies for group therapy & $\begin{array}{l}\text { Training for participation in groups and modification } \\
\text { and fixing the functions }\end{array}$ & Group \\
\hline Session 9 & & $\begin{array}{l}\text { Life skills training (self-management, self-decision, } \\
\text { self-efficacy, and self-control) }\end{array}$ & Group \\
\hline Session 10 & & Problem solving skill training & Group \\
\hline
\end{tabular}

Table 2 Demographic information in the control and experimental groups

\begin{tabular}{|c|c|c|c|c|c|c|c|}
\hline \multirow[t]{2}{*}{ Variable } & \multirow[t]{2}{*}{ Variable levels } & \multicolumn{2}{|c|}{ Experimental group } & \multicolumn{2}{|c|}{ Control group } & \multicolumn{2}{|l|}{ Total } \\
\hline & & Frequency & $\overline{\text { Percentage }}$ & Frequency & $\overline{\text { Percentage }}$ & Frequency & Percentage \\
\hline \multirow[t]{3}{*}{ Educational level } & Under high school & 10 & 33.3 & 8 & 26.6 & 18 & 30 \\
\hline & $\begin{array}{l}\text { High school } \\
\text { graduate }\end{array}$ & 18 & 60 & 21 & 70 & 39 & 65 \\
\hline & Bachelor and higher & 2 & 6.6 & I & 3.3 & 3 & 5 \\
\hline \multirow[t]{4}{*}{ Age range (years) } & $20-30$ & 14 & 46.6 & II & 36.6 & 25 & 41.6 \\
\hline & $30-40$ & 7 & 23.3 & 13 & 43.3 & 20 & 33.3 \\
\hline & $40-50$ & 6 & 20 & 5 & 16.6 & 11 & 18.3 \\
\hline & $50-60$ & 3 & 10 & I & 3.3 & 4 & 6.6 \\
\hline Duration of addiction & $2-4$ & 6 & 20 & 5 & 16.6 & 11 & 18.3 \\
\hline \multirow[t]{2}{*}{ (years) } & $4-6$ & 18 & 60 & 17 & 56.6 & 35 & 58.3 \\
\hline & $6-8$ & 6 & 20 & 8 & 26.6 & 14 & 23.3 \\
\hline \multirow[t]{3}{*}{ Type of addiction } & Opium & 8 & 26.6 & 10 & 33.3 & 18 & 30 \\
\hline & Heroin & $\mathrm{I}$ & 3.3 & 2 & 6.6 & 3 & 5 \\
\hline & Both & 18 & 60 & 21 & 70 & 39 & 65 \\
\hline \multirow[t]{3}{*}{ Economic status } & $\begin{array}{l}\mathrm{I}, 000,000-2,000,000 \\
\text { rials }\end{array}$ & 5 & 16.6 & 3 & 10 & 8 & 13.3 \\
\hline & $\begin{array}{l}2,000,000-3,000,000 \\
\text { rials }\end{array}$ & 12 & 40 & 15 & 50 & 27 & 45 \\
\hline & $>3,000,000$ rials & 13 & 43.3 & 12 & 40 & 25 & 41.6 \\
\hline \multirow[t]{4}{*}{ Occupational status } & Workman & 13 & 43.3 & 10 & 33.3 & 23 & 38.3 \\
\hline & Office worker & 2 & 6.6 & 1 & 3.3 & 3 & 5 \\
\hline & Self-employed & 7 & 23.3 & 12 & 40 & 19 & 31.6 \\
\hline & Jobless & 8 & 26.6 & 7 & 23.3 & 15 & 25 \\
\hline
\end{tabular}

\section{Findings related to hypothesis testing}

A comparison of the mean pretest scores in aspects of general health test in both intervention and control groups were specified based on the independent $t$-test results. There was no statistically significant difference between the total score of general health in both groups with regard to four aspects, including somatic symptoms, anxiety and insomnia, social dysfunction, and depression. Thus, the scores of all the indexes and the total score in the case and control groups are assumed to be the same before intervention (Table 4).

Considering the results obtained from the dependent $t$-test (Table 5), social work intervention is proved to be effective in the improvement of all aspects of general health and posttest scores are significantly higher than pretest scores. 
Table 3 Normality distributions for variables (before and after intervention)

\begin{tabular}{|c|c|c|c|c|c|c|c|}
\hline \multirow[t]{2}{*}{ Group } & \multirow[t]{2}{*}{ Variable } & \multicolumn{3}{|c|}{ Before intervention } & \multicolumn{3}{|c|}{ After intervention } \\
\hline & & $\bar{Z}$ & $P$-value & Result & $\bar{Z}$ & $P$-value & Result \\
\hline \multirow[t]{2}{*}{ Intervention } & Total score of relapse prevention & 1.26 & 0.08 & Normal & 0.917 & 0.37 & Normal \\
\hline & Total score of general health & 0.643 & 0.8 & Normal & 0.647 & 0.797 & Normal \\
\hline \multirow[t]{2}{*}{ Control } & Total score of relapse prevention & 0.334 & 1 & Normal & 0.396 & 0.998 & Normal \\
\hline & Total score of general health & 0.67 & 0.761 & Normal & 0.551 & 0.92 & Normal \\
\hline
\end{tabular}

Table 4 Independent $t$-test results of two independent samples for comparing pretest scores in the case and control groups

\begin{tabular}{|c|c|c|c|c|c|c|}
\hline \multirow[t]{2}{*}{ Index } & \multirow[t]{2}{*}{ Group } & \multirow[t]{2}{*}{ Mean } & \multicolumn{2}{|c|}{$\begin{array}{l}\text { Homogeneity of } \\
\text { variances test }\end{array}$} & \multicolumn{2}{|c|}{$\begin{array}{l}\text { Equality of } \\
\text { means test }\end{array}$} \\
\hline & & & $F$ & $P$-value & $T$ & $P$-value \\
\hline Somatic & Intervention & 6.33 & 6.7 & 0.000 & 0.825 & 0.36 \\
\hline symptoms & Control & 5.98 & & & & \\
\hline Anxiety and & Intervention & 7.15 & 1.59 & 0.211 & 1.32 & 0.42 \\
\hline insomnia & Control & 7.01 & & & & \\
\hline Social & Intervention & 7.46 & 0.369 & 0.546 & 1.88 & 0.12 \\
\hline dysfunction & Control & 6.8 & & & & \\
\hline \multirow[t]{2}{*}{ Depression } & Intervention & 3.1 & 0.451 & 0.505 & 1.07 & 0.287 \\
\hline & Control & 3.73 & & & & \\
\hline Total score & Intervention & 25.6 & 3.6 & 0.302 & 1.02 & 0.325 \\
\hline $\begin{array}{l}\text { of general } \\
\text { health }\end{array}$ & Control & 24.9 & & & & \\
\hline
\end{tabular}

Table 5 Dependent $t$-test results of two dependent samples for investigating the intervention effect in the intervention group for the general health variable and its dimensions in posttest

\begin{tabular}{lllll}
\hline Index & $\begin{array}{l}\text { Before } \\
\text { intervention }\end{array}$ & $\begin{array}{l}\text { After } \\
\text { intervention }\end{array}$ & \multicolumn{2}{l}{$\begin{array}{l}\text { Equality of means } \\
\text { test }\end{array}$} \\
\cline { 3 - 5 } & & T-value & P-value \\
\hline $\begin{array}{l}\text { Somatic } \\
\text { symptoms }\end{array}$ & 4.81 & 3.4 & 4.6 & 0.000 \\
$\begin{array}{l}\text { Anxiety and } \\
\text { insomnia }\end{array}$ & 6.25 & 4.6 & 4.63 & 0.000 \\
$\begin{array}{l}\text { Social } \\
\text { dysfunction }\end{array}$ & 6.63 & 5.21 & 7.49 & 0.000 \\
$\begin{array}{l}\text { Depression } \\
\text { Total score of } \\
\text { general health }\end{array}$ & 4.05 & 3.41 & 2.96 & 0.004 \\
\hline
\end{tabular}

\section{Covariance analysis results}

In order to make a comparison of posttest scores in the intervention and control groups, covariance analysis was used with an adjustment of the posttest scores through pretest scores. Hence, a systematic approach to the influence of social work intervention with regard to increasing general health on opioid addicts was investigated.

Considering the data in Tables 6 and 7, it can be concluded that social work intervention with a systematic approach statistically influenced an increase in general health of opioid addicts $\left(P<0.05, \eta^{2}=0.167\right)$.
Table 6 Covariance analysis of effect of social work intervention with a systematic approach to improve general health in opioid addicts

\begin{tabular}{lllllll}
\hline Variable & $\begin{array}{l}\text { Sum of } \\
\text { squares }\end{array}$ & df & $\begin{array}{l}\text { Mean } \\
\text { square }\end{array}$ & $\boldsymbol{F}$ & Significant & $\boldsymbol{\eta}^{2}$ \\
\hline $\begin{array}{l}\text { General health } \\
\text { pretest score }\end{array}$ & 2661.34 & I & 2661.34 & 183.35 & 0.000 & 0.763 \\
$\begin{array}{l}\text { Group (control- } \\
\text { intervention) }\end{array}$ & $166.1 \mathrm{I}$ & $\mathrm{I}$ & $\mathrm{I} 66.1 \mathrm{I}$ & $\mathrm{II} .44$ & $0.00 \mathrm{I}$ & 0.167 \\
\hline $\begin{array}{l}\text { Note: Dependent variable: posttest score of general health. } \\
\text { Abbreviation: } d f \text {, degrees of freedom. }\end{array}$ & & & & \\
\hline
\end{tabular}

Table 7 Preadjusted and adjusted mean in two groups

\begin{tabular}{|c|c|c|c|c|c|}
\hline \multirow[t]{2}{*}{ Group } & \multirow[t]{2}{*}{$\begin{array}{l}\text { Number } \\
\text { of subjects }\end{array}$} & \multirow[t]{2}{*}{$\begin{array}{l}\text { Preadjusted } \\
\text { mean }\end{array}$} & \multirow[t]{2}{*}{$\begin{array}{l}\text { Adjusted } \\
\text { mean }\end{array}$} & \multicolumn{2}{|c|}{$\begin{array}{l}95 \% \text { Confidence } \\
\text { interval }\end{array}$} \\
\hline & & & & $\begin{array}{l}\text { Lower } \\
\text { limit }\end{array}$ & $\begin{array}{l}\text { Upper } \\
\text { limit }\end{array}$ \\
\hline Intervention & 30 & 17.2 & 14.82 & 13.43 & 16.3 \\
\hline Control & 30 & 16.06 & 18.39 & 16.96 & 19.83 \\
\hline
\end{tabular}

In addition, covariance analysis was performed to evaluate the influence of social work intervention with a systematic approach to general health aspects. The results suggested that social work influences somatic symptoms, social dysfunction, and depression in opioid addicts $(P<0.05)$. However, social work intervention with systematic approach did not influence insomnia and anxiety status in opioid addicts $(P<0.05)$.

\section{Discussion}

Addiction is a factor that endangers the general health of human beings and leads to disorders in their biological, psychological, and social behaviors. There are various factors involved in the emergence of addiction, including individual (age, personality traits, genetics, mental disorders, risky situations, positive attitudes to the drug, and the influence of drugs on the person), education, media, leisure, social, economic, political, geographical, and family factors. ${ }^{17,18}$

Attention to nonpharmacological treatment is essential in the treatment of addiction, and mental health status is one of the factors that is especially important in the etiology and addiction treatment process; it is often forgotten during the treatment process. $^{21}$ 
This study focused on the use of systematic intervention of social work, which is a nonpharmacological method, and also aimed to examine its impact on general health of opioid addicts. The results of the present study indicated that the power of the intervention effect on general health was roughly $16.7\left(\eta^{2}\right)$, which means that social work intervention was effective in increasing general health.

The findings of the study are consistent with Amiri et al's behavioral activation group therapy. ${ }^{22}$ Contrary to the results of Erfani et al, ${ }^{23}$ who had shown that the intervention of self-acceptance group therapy by Dryden method was not effective in improving physical symptoms and social functions of addicts, it seems that the social work can improve addicts' individual and social functions.

Based on research findings about reasons behind beginning addiction and its relapse following treatment, different factors such as improper mental health have been mentioned. General health plays an important role in the etiology and treatment process of addicted individuals. The presence of accompanying mental disorders causes resistance to treatment and relapse of addiction. ${ }^{24-26}$ Accordingly, one of the issues that should be considered in the interpretation of the research findings is improvement of the mental health for these individuals. This is because, according to Khantzian's self-medication theory, ${ }^{28-30}$ drug abuse by addict individuals is regarded as a kind of self-treatment. People become addicted to drugs to solve problems such as depression and it is, therefore, likely that social work intervention with a systematic approach can influence the reduction of relapse in addicts, which is suggested to be investigated in future research.

The results of the study addressed the efficacy of social work intervention on general health aspects based on a GHQ. They showed that the power of the effect of the social work intervention on physical condition, a subcategory of general health, was $12.3\left(\eta^{2}\right)$, which demonstrates the efficacy of social work intervention on improving general health in terms of physical condition. This finding agrees with the results of Kamarzarin et al, ${ }^{31}$ who illustrated the effectiveness of cognitive-behavioral therapy on increasing the self-efficiency and improving the mental and physical health of people addicted to opioid and are also compatible with Behravan and Mir-Anvaari' ${ }^{32}$ findings. They found that structural factors, including social structure, social class, social satisfaction, feeling discriminated against in life, and achieving the life goals with success, can contribute to increase or decrease in drug relapse. The results of the study showed that the power of the effect of the social work intervention on increasing general health in terms of social dysfunction was 20.8 $\left(\eta^{2}\right)$. This finding indicates that social work intervention is effective in reducing social dysfunctioning. It is consistent with Kaldi ${ }^{33}$ and Ma'arefvand, ${ }^{34,35}$ who studied the association between structural-functional variables and addiction relapses. It turned out that increasing social satisfaction of addicts after treatment reduced the frequency of the addiction relapse. They, therefore, found that all structural-functional variables are strongly associated with the frequency of addiction relapses. The research findings of Yazdani ${ }^{36}$ likewise indicated that functional social support was higher in patients without addiction relapse after rehabilitation than in patients with addiction relapse after abstinence. The results of the research illustrated that the power of the effect of the social work intervention on improving general health in terms of depression status was $15.2\left(\eta^{2}\right)$. This is supported by the findings of Middel ${ }^{37}$ and Baker et al, ${ }^{38}$ who demonstrated the efficiency of cognitive-behavioral therapy in reducing depression in alcohol addicts.

\section{Conclusion}

Studying the effect of systematic intervention of social work on general health, the social work model consists of various dimensions, based on which the opioid addicts are considered as a set of biological, psychological, social, and family aspects. In the beginning, social workers started their work with motivational interviewing; then, the cognitive and diagnostic aspects of the intervention began. At this stage, the characteristics of the addict and his/her problems were evaluated. In the evaluation of the addicted people's features, the following factors were taken into consideration: assessment of mental health, evaluation of social and familial status, drawing genogram and eco-mapping, evaluation of addict's attitudes toward addiction, assessment of needs and functions, social capital and social support resources. In the evaluation of problem, the etiology, dynamics, and clinical parameters of addiction problem were considered. After examining the addict and his/her problem, strategies for solving problems were designed and used. These strategies were including, in particular, changing the addict's attitude toward addiction, reforming family relations and interpersonal communications, solving family problems, and improving the support resources. The impaired functions of the addict were corrected, or new functions were defined for him/her. In the systematic intervention based on social work, life skills training with an emphasis on improving interpersonal relationships, problem solving, self-decision making, improving self-confidence, and increasing self-efficacy and self-management was performed in the form of developmental group work.

The results indicated that systematic intervention of social work based on group and case work was effective on general 
health of the addicts, improved the biological aspects of general health (based on a GHQ) and social functioning, and reduced their depression. Independent and dependent $t$-test showed the efficacy of this intervention in reducing anxiety and improving sleeping. In this study, the nature of the presence of social workers at addiction clinics can contribute to general health and can prevent relapse, reduce anxiety and insomnia, increase self-recognition and cognition of strategies for coping with stress, and improve the proper social behavior.

\section{Limitations}

The researchers faced some limitations in this intervention including the few numbers of studies focusing on the social work intervention and nonwillingness of participants to enter the study due to addiction problem; hence, we tried to motivate them to answer the questionnaire and participate in the treatment sessions.

\section{Acknowledgments}

The authors sincerely thank the vice-chancellor for Research and Technology, University of Social Welfare and Rehabilitation Sciences, for financial support of this research project. The authors are grateful to directors, managers of the drug addiction treatment centers in the Guilan Province who helped them during implementing the tests, and all of the patients who participated in the project.

\section{Author contributions}

All authors contributed toward data analysis, drafting and critically revising the paper and agree to be accountable for all aspects of the work.

\section{Disclosure}

The authors report no conflicts of interest in this work.

\section{References}

1. Velasquez MM. Group Treatment for Substance Abuse. New York: Guilford Press; 2001.

2. Moghanibashi-Mansourieh A, Deilamizade A. The state of data collection on addiction in Iran. Addiction. 2014;109(5):854.

3. Burns L. World Drug Report 2013 By United Nations Office on Drugs and Crime New York: United Nations, 2013ISBN: 978-92-1-056168-6, 151 pp. Grey literature. Drug Alcohol Rev. 2014;33(2):216.

4. Sadock B, Sadock V. Synopsis of Psychiatry. 9th ed. Philadelphia, Baltimore, New York: Lippincott Williams \& Wilkins; 2003.

5. Kessler RC, Brandenburg N, Lane M, et al. Rethinking the duration requirement for generalized anxiety disorder: evidence from the National Comorbidity Survey Replication. Psychol Med. 2005;35(07):1073-1082.

6. Shahidi S, Jafari M. Comparing locus of control, assertiveness and general health among young drug addicts in Iran. Iran J Psychiatry. 2009;4(2):46-51.

7. Sohrabi F. Problem of Cigarette in the Mirror of Research Study on Effective Facts in Attitude on the Students to Cigarette. Tehran: Madraseh Publications; 2004.
8. Alimoradi L. The comparing activity of brain/behavioral systems and mental health in normal and addict's individuals. Procedia Soc Behav Sci. 2011;30:1703-1708.

9. Hoseinifar J, Zirak SR, Shaker A, Meamar E, Moharami H, Siedkalan MM. Comparison of quality of life and mental health of addicts and non-addicts. Procedia Soc Behav Sci. 2011;30:1930-1934.

10. Moallemi S, Raghibi M, Salari Dargi Z. Comparison of spiritual intelligence and mental health in addicts and normal individuals. J Shahid Sadoughi Univ Med Sci. 2010;18(3):234-242.

11. Serajkhorami N, Isfahanieasl M, editors. [The effect of addiction treatment on mental health, self-esteem and moral judgment in addicts]. National Congress of Social and Psycho-Pathology. Tehran: Islamic Azad University; 2008:10-15. Persian.

12. Graipaspong D. Mental health and defenses mechanism of Thai inmates and prisoners. Eur Psychiatry. 2010;25:741.

13. Pierson FM, Fairchild SL. Principles \& Techniques of Patient Care. 4th ed. Philadelphia, PA: W B Saunders; 2008.

14. Wells EA, Kristman-Valente AN, Peavy KM, Jackson TR. Social workers and delivery of evidence-based psychosocial treatments for substance use disorders. Soc Work Public Health. 2013;28(3-4):279-301.

15. Hepworth D, Rooney R, Rooney GD, Strom-Gottfried K, Larsen JA. Direct Social Work Practice: Theory and Skills. 9th ed. Pacific Grove, CA: Brooks/Cole Publishers; 2013.

16. Glasner-Edwards S, Rawson R. Evidence-based practices in addiction treatment: review and recommendations for public policy. Health Policy. 2010;97(2):93-104.

17. Eghlima M, Raheb G. Methods of Social Work in Prevention and Treatment of Addiction. Tehran: University of Social Welfare and Rehabilitation Sciences Press; 2010.

18. Eghlima M, Raheb G. Individual Work with Individual. Tehran: Danzheh Publications; 2010.

19. Goldberg D. Manual of the General Health Questionnaire. NFER Nelson; London: Oxford University Press; 1978.

20. Goldberg DP, Hillier VF. A scaled version of the General Health Questionnaire. Psychol Med. 1979;9(01):139-145.

21. Mollazadeh J, Ashouri A. Evaluate the effectiveness of cognitivebehavioral therapy in preventing recurrence and improving mental health in addicts. Daneshvar Raftar. 2009;16(34):1-12.

22. Amiri M, Yazdandoust RY, Tabatabaei SM. Effectiveness of group behavioral activation treatment in reducing depressive symptoms and effects of this treatment in increasing mental health and quality of life in clients of therapeutic community. J Res Addict. 2009;3(9):101-114.

23. Erfani N, Zare Bahramabadi M, Mashayekhi Pour M. Effectiveness of self-acceptance group therapy by Dryden method on mental health components addiction of quitting institute. J Clin Psychol. 2013;5(2): $25-35$.

24. Pollack MH, Otto MW, Rosenbaum JF. Challenges in Clinical Practice: Pharmacologic and Psychosocial Strategies. New York-London: The Guilford Press; 1996.

25. Gastfriend DR. When a substance use disorder is the cause of treatment resistance. In: Pollack MH, Otto MW, Rosenbaum JF, editors. Challenges in Clinical Practice: Pharmacologic and Psychosocial Strategies. New York, NY: The Guilford Press; 1996:329-354.

26. Booth RE, Corsi KF, Mikulich-Gilbertson SK. Factors associated with methadone maintenance treatment retention among streetrecruited injection drug users. DrugAlcohol Depend. 2004;74(2):177-185.

27. Baschnagel JS, Coffey SF, Schumacher JA, Drobes DJ, Saladin ME. Relationship between PTSD symptomatology and nicotine dependence severity in crime victims. Addict Behav. 2008;33(11):1441-1447.

28. Khantzian EJ. The self-medication hypothesis of addictive disorders: focus on heroin and cocaine dependence. Am J Psychiatry. 1985;142(11):1259-1264.

29. Khantzian EJ. The self-medication hypothesis of substance use disorders: a reconsideration and recent applications. Harv Rev Psychiatry. 1997;4(5):231-244.

30. Khantzian EJ, Albanese MJ. Understanding Addiction as Self Medication: Finding Hope Behind the Pain. New York: Rowman \& Littlefield Publishers; 2008. 
31. Kamarzarin H, Zareei H, Brouki M. The effectiveness of cognitive behavioral therapy on increasing of self-efficacy and improving of addiction symptoms among drug dependency patients. Res Addict. 2012;6(22):75-85.

32. Behravan H, Mir-Anvaari SAR. A sociological analysis of drug addict's relapse in the therapeutic community of Mashhad, Iran. Iran J Soc Probl. 2010;1(1):45-78.

33. Kaldi A. The role of internal and external locus of control in relapse of addiction in occupational therapy camp of Zanjan. Soc Welf. 2003;3(9): 307-331

34. Ma'arefvand MS. Examining the Personal and Familial Causes and Social Relationships Influencing on Relapse of Recovered Addicts. Tehran, Iran: University of Social Welfare and Rehabilitation Sciences; 2002 .
35. Ma'arefvand MS. Evaluation of Community-Based Interventions for the Prevention of Relapse in Addicts During Abstinence-Based and Faith-Based Treatment. Tehran, Iran: University of Social Welfare and Rehabilitation Sciences; 2011.

36. Yazdani M. Comparison of Social Support Between People Who Have Relapsed after Discontinuation of the Drug and People Who Have Not Had Recurrence at Camp Rebirth in Tehran City. Tehran, Iran University of Social Welfare and Rehabilitation Sciences; 2011.

37. Middel B. Randomized controlled trial of cognitive-behavioural therapy for coexisting depression and alcohol problems: short-term outcome. Nederlands Tijdschrift voor Evid Based Pract. 2010;8(3):9-10.

38. Baker AL, Kavanagh DJ, Kay-Lambkin FJ, et al. Randomized controlled trial of cognitive - behavioural therapy for coexisting depression and alcohol problems: short-term outcome. Addiction. 2010;105(1):87-99.
Psychology Research and Behavior Management

\section{Publish your work in this journal}

Psychology Research and Behavior Management is an international, peerreviewed, open access journal focusing on the science of psychology and its application in behavior management to develop improved outcomes in the clinical, educational, sports and business arenas. Specific topics covered in the journal include: Neuroscience, memory and decision making; Behavio

\section{Dovepress}

modification and management; Clinical applications; Business and sports performance management; Social and developmental studies; Animal studies. The manuscript management system is completely online and includes a very quick and fair peer-review system, which is all easy to use. Visit http://www. dovepress.com/testimonials.php to read real quotes from published authors.

Submit your manuscript here: https://www.dovepress.com/psychology-research-and-behavior-management-journal 